MATEC Web of Conferences 53, 01038 (2016)

DOI: $10.1051 /$ matecconf $/ 20165301038$

(C) Owned by the authors, published by EDP Sciences, 2016

\title{
Sandwich Panel as a Structural Element of Overlap
}

\author{
Maxim Novikov ${ }^{1 \mathrm{a}}$, Vyacheslav Polushin ${ }^{2}$ and Sergey Zimin $^{3}$ \\ ${ }^{1,3}$ St. Petersburg State Polytechnical University, Politekhnicheskaya, 29, Saint-Petersburg, 195251, Russia \\ ${ }^{2}$ OOO "Yoris Ide", Kooperativnaya, 1A, Leningrad region, Gatchinsky district, 188349, Russia
}

\begin{abstract}
This paper considers the issue of sandwich panels using as load-bearing structural elements. The comparison of deflections and critical failure loads were obtained by the results of the full-scale roof sandwich panels tests conducted by the company "Joris Ide" and the theoretical design, according to the calculation method described in Euronorms. Based on these results it was concluded that sandwich panels can be treated as a load-bearing structure only with more taught manufacturing requirements. Thus, the reduced spread of critical loads can be achieved.
\end{abstract}

\section{Introduction}

Ceiling is very important constructive element in building, that's why it will be always actual, to find optimal solution in this sphere.

In our days reinforced concrete is the most popular material for construction ceiling. It is strong enough, durable and fire-resistant. But it has some shortcomings, the main shortcoming is own weight load comparing with effective load, that constriction perceive. In addition, when the premises are presented the individual requirements of the thermal insulation to the own weight of overlap added weight envelopes. That's why it is not rationally to use it when requirements to ceiling aren't high, otherwise it could cause increase of load on bearing elements, and hence cause increasing of cross-section of columns, beams, size and price of foundation. All this greatly affects the cost of the building as a whole.

Eventu2 ally arise a number of cases, when it must be taken another material, which also meet the requirements of strength, fire-resistant, thermal conductivity (if such requirements imposed), but it would had significantly lower weight. Sandwich panels could be used as such material, which can combine functions of both constructive elements and walling.

Sandwich panels - frameless three-layered product, in which the individual layers are glued together. For external and internal layers used galvanized steel sheet coated, profiled or smooth, and for the middle layer insulation of expanded polystyrene or mineral fiber [1].

The question of the sandwich panels, most often comes up when discussing the construction of prefabricated buildings. Usually it is the building for production purposes, the construction of which is carried out continuously. But despite the obvious relevance of use of this material is limited. This is due to the fact that the thermal engineering calculation is widely studied [2-11], which allows us to use sandwich panels as walling. However issues of technological and regulatory plan and strength calculation remain open and require active discussion [12].

In Russian regulatory literature, there are no calculation method by which with reasonable certainty can be assessed strength properties of sandwich panels. But if you try to start using this material as the loadbearing structural elements it is necessary to enter of such a method. According to EA, Petrova [13] in the

\footnotetext{
${ }^{a}$ Corresponding author: maximnn1720@gmail.com
}

This is an Open Access article distributed under the terms of the Creative Commons Attribution License 4.0, which permits unrestricted use, distribution, and reproduction in any medium, provided the original work is properly cited. 


\section{MATEC Web of Conferences}

European Union for over 20 years, there are regulations dedicated to this issue, but before the application of these instruments on the territory of Russia, they need to be adapted to the realities of our country.

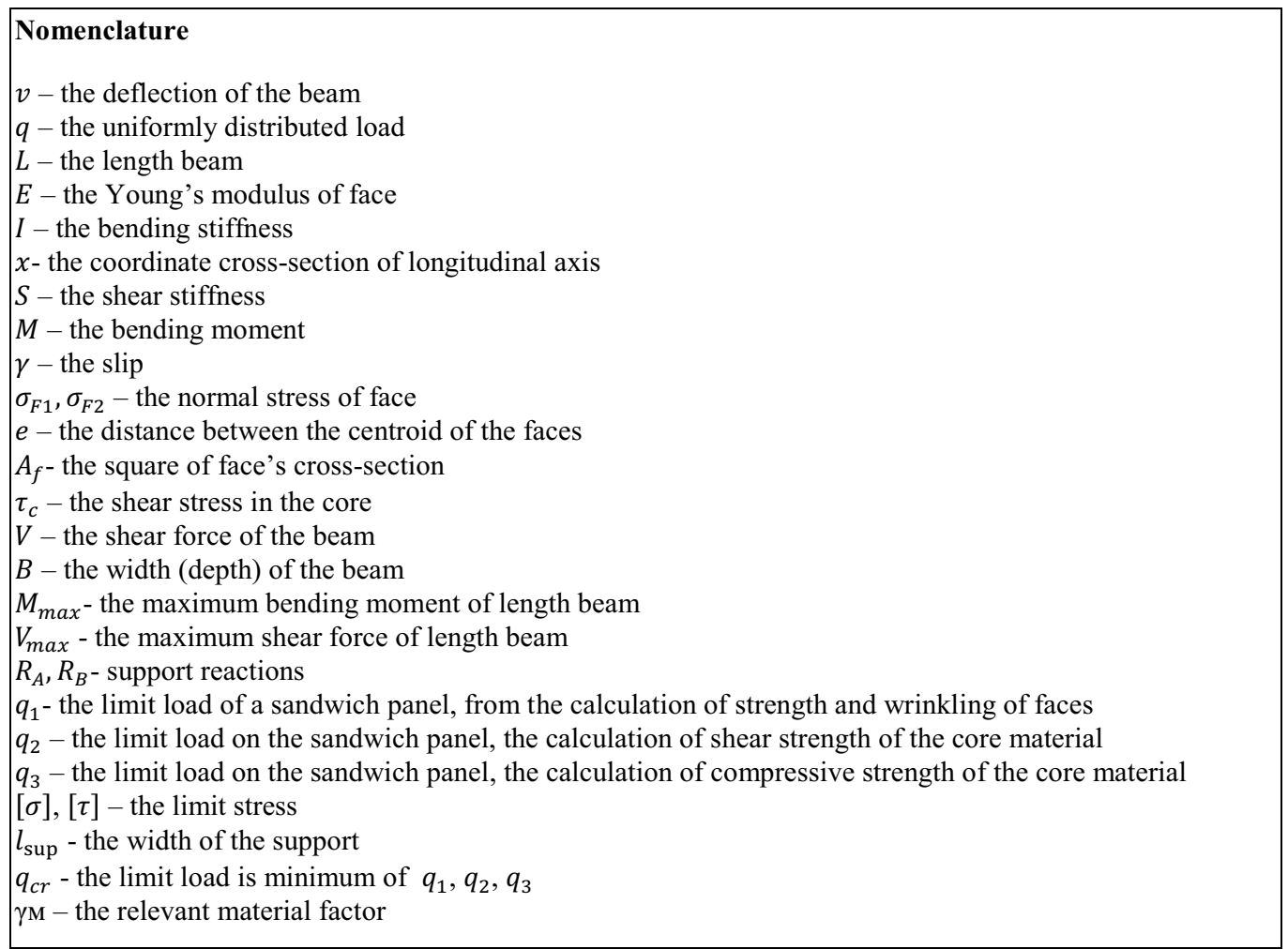

\section{Review of the literature}

Review of the national regulatory literature showed no documents, allowing to make the calculation of a "sandwich" - panels. The only exception is the recommendation [14], which are not mandatory and that not all options are taken into account fracture mechanisms, in particular shear failure of the middle layer, the middle layer of compressive, shear strength in the long-term load.

However, in the literature can be found works, dedicated to search for optimal methods of calculating both the "sandwich" - panels, and nodes of their interface with other design elements, such as OA Tusnina in his articles [15,16] described the method of calculation of conjugation z-shaped run with a "sandwich" panel. Mircea Georgescu [17] and Marcin Kujawa [18] are also exploring this problem. Kahina Saad Saoud [19] considers the problem of general and local loss of compressed facing. Robert Studziński [20] explores the impact of microprofiling of facing on the bearing capacity of sandwich panels. Bronisław Kosowski [21] in his article offers calculation of multispan sandwich panels with intermediate supports elastic pliability under the influence of uniformly distributed load and stress caused by the difference in temperature.

The presence of scientific works confirms the relevance of the question.

S. Petrov in his article [22] gives the experimental results which show that the work of sandwich panels can be represented as a beam, working on a bend of the uniformly distributed load with uniform distribution of the normal stresses in the facing to the width of the panel, considering that the average a layer of insulation is works only for shear and due to local deformation of the facing of the reaction steps, it is necessary to set the support is elastic pliability. In [23] he described a theoretical method for determining the 
stress-strained state of sandwich panels using these assumptions. The given experimental data confirm the validity of calculations. However, the described method time consuming and takes quite a lot of time, for this reason, the author was forced to write a program [24], allowing to make the calculation more quickly. But this approach also has drawbacks, such as the program describes a finite number of individual cases, so it does not turn out to apply in every situation. Therefore European standards [25, 26], offer a method of calculation for the simplified design scheme. It is assumed that you can ignore the impact of compliance supports, if you enter a check for a deformation of the metal supports. This approach greatly simplifies the calculations while the results are still quite accurately coincide with the full-scale tests.

\section{Statement of the Problem.}

The purpose of this paper is to analyze the proposed European standards methodology for assessing stressstrained state of sandwich panels and determine the characteristics that should be taken into account when considering the material as a carrier component.

\section{Materials and Methods}

\subsection{Experimental studies.}

Tests of wall sandwich panels MEGA made by order of the company "Joris Ide", were conducted in accordance with [27], the purpose of which was to determine the strength of the sample panels at lateral bending. According to [23]. The problem can be reduced to the calculation of the beam pattern, as the stress across the width in the same section does not vary significantly, so the model was a one span slab-beam with a uniformly distributed load applied over the entire width of the panel. The load was applied gradually. After each stage of the application load, the testing product is kept under load till full stabilization of the deflection for 5 minutes. During this time, the value of the load was kept constant.

Were tested sandwich panels MEGA brands SP-Z-100-MV and MEGA SP-Z-150-MV. Three samples of each brand were tested for spans of 4 and 6 meters. The thickness of the metal facings $0.5 \mathrm{~mm}$, insulation of mineral wool brand "Tehnosendvich C", a two-component polyurethane glue Daltofoam 44203-Suprasek 2026. To measure the deflection in the middle of the panels and deformation of the supports and displacement in the longitudinal direction of the facings six deflection meters PAO 6 were install, one at mid-span, two devices in the immediate vicinity of the supports and one on the end panel.

The samples were brought to the exhaustion of the panels bearing capacity (to failure). According to data of tests plotted dependence of deflection at mid-span of the applied load.

\subsection{Theoretical studies.}

In [26] proposed a method for calculation of sandwich panels as a result of which can be obtained analytically plots deflection at mid-span of the applied load and compare with the data of full-scale tests.

According to this method, the middle layer materials and facings for the given range of deformation are linear elastic. Rigidity in tension of the middle layer as compared with the rigidity of the tensile facings so small that the influence of the normal stress in the middle layer can be disregarded. Because of these assumptions, the bearing capacity of sandwich panels with thin and smooth or slightly profiled facings running on pure bending can be divided into two components - the carrying capacity of facings, sensing compressive and tensile forces from the bending moment and the carrying capacity of the middle layer, the sensing stress shift. As a result, according to [26] equation of the bent-axis will be by formula 1 :

$$
-E I v^{\prime \prime}=M-E I \gamma^{\prime}
$$




\section{MATEC Web of Conferences}

In the case of a uniformly loaded one span beam, after integration, we obtain an expression for calculating the values of the movement:

$$
v=\frac{1}{24} \frac{q L^{4}}{E I}\left[\left(\frac{x}{L}\right)^{4}-2 \cdot\left(\frac{x}{L}\right)^{3}+\left(\frac{x}{L}\right)\right]+\frac{q}{2 S}\left(L x-x^{2}\right)
$$

The characteristic values of resistance for sandwich panels are shown in Table 1

Table 1. Normative values of resistance.

\begin{tabular}{|c|c|}
\hline Normative values of resistance & Values \\
\hline Yield strength of the faces & $230 \mathrm{MPa}$ \\
\hline Compressive strength of the core materials & $0.06 \mathrm{MPa}$ \\
\hline Wrinkling strength of the faces & $90.51 \mathrm{MPa}$ \\
\hline
\end{tabular}

The normal stress in the faces can be determined from the expression 3, according [25]

$$
\sigma_{F 1}=\sigma_{F 2}=\frac{M}{e \cdot A_{f}}
$$

The shear stress in the core is calculated by formula 4, according [25]

$$
\tau_{c}=\frac{V}{e \cdot B}
$$

Maximum bending moment, shear force and values support reactions for case one-span sandwich-panel with uniformly distributed load can be determined from the expressions 5, 6

$$
\begin{gathered}
M_{\text {max }}=\frac{q L^{2}}{8} \\
V_{m q x}=R_{A}=R_{B}=\frac{q L}{2}
\end{gathered}
$$

Therefore, it is possible to obtain the values of critical load:

1. For case of normal stress in the faces by formula 7

$$
q_{1}=\frac{[\sigma] \cdot 8 e A_{f}}{L^{2}}
$$

For case of shear stress in the core by formula 8

$$
q_{2}=\frac{[\tau] \cdot 2 e B}{L}
$$


2. For case of compressive stress in the core by formula 9

$$
q_{3}=\frac{2 \cdot l_{\text {sup }} \cdot B \cdot[\sigma]}{L}
$$

\section{Results and Discussion}

The values of critical loads, taking into account the relevant material factor shown in Table 2 .

The dependences deflection of the beam from uniformly distributed load, according to data of test sandwich-panels and theoretical calculation are presented at figure 1,2,3.

Table 2. The value of critical loads

\begin{tabular}{|c|c|c|c|}
\hline & $\begin{array}{c}\text { The length of } \\
\text { span }\end{array}$ & Limit load, $q_{c r}$ & The damage mechanisms \\
\hline \multirow{3}{*}{$\begin{array}{c}\text { MEGA SP-Z- } \\
\text { 100-MV }\end{array}$} & $\mathrm{L}=4 \mathrm{~m}$ & $\begin{array}{c}2.274 \mathrm{kN} / \mathrm{m} 2 \\
(1.819 \mathrm{kN} / \mathrm{m} 2)\end{array}$ & $\begin{array}{c}\text { Wrinkling of compressed face in the } \\
\text { span }\left(\gamma_{\mathrm{M}}=1.25\right)\end{array}$ \\
\cline { 2 - 4 } & $\mathrm{L}=6 \mathrm{~m}$ & $\begin{array}{c}1.011 \mathrm{kN} / \mathrm{m} 2 \\
(0.809 \mathrm{kN} / \mathrm{m} 2)\end{array}$ & $\begin{array}{c}\text { Wrinkling of compressed face in the } \\
\text { span }\left(\gamma_{\mathrm{M}}=1.25\right)\end{array}$ \\
\hline & $\mathrm{L}=4 \mathrm{~m}$ & $\begin{array}{c}3.00 \mathrm{kN} / \mathrm{m} 2 \\
(2.40 \mathrm{kN} / \mathrm{m} 2)\end{array}$ & $\begin{array}{c}\text { Compression of the core over a support } \\
\left(\gamma_{\mathrm{M}}=1.4\right)\end{array}$ \\
\cline { 2 - 4 } $\begin{array}{c}\text { MEGA SP-Z- } \\
\text { 150-MV }\end{array}$ & $\mathrm{L}=6 \mathrm{~m}$ & $\begin{array}{c}1.514 \mathrm{kN} / \mathrm{m} 2 \\
(1.211 \mathrm{kN} / \mathrm{m} 2)\end{array}$ & $\begin{array}{c}\text { Wrinkling of compressed face in the } \\
\text { span }\left(\gamma_{\mathrm{M}}=1.25\right)\end{array}$ \\
\cline { 2 - 4 } & & &
\end{tabular}

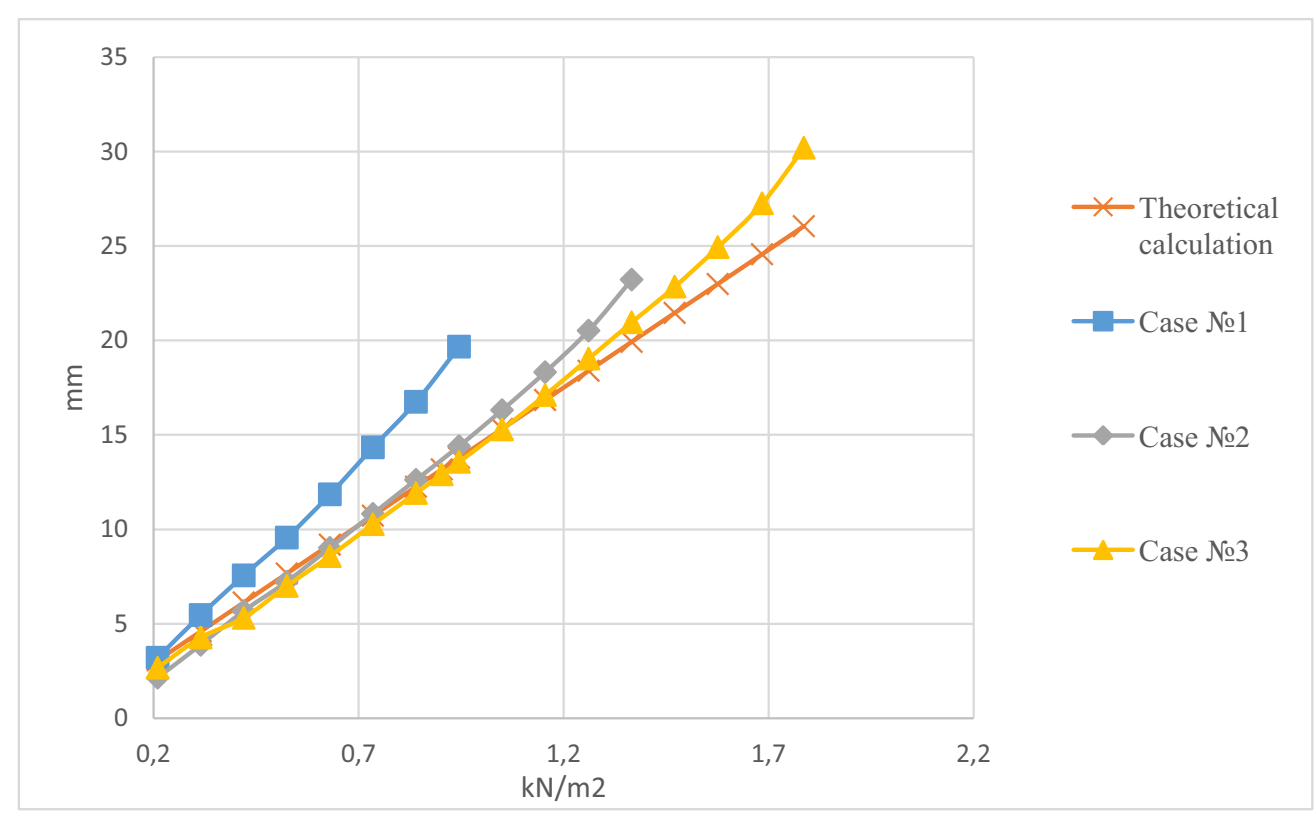

Figure 1. The dependence deflection of the beam from uniformly distributed load, according to data of test sandwichpanels MEGA SP-Z-100-MV with $4 \mathrm{~m}$ span and theoretical calculation 


\section{MATEC Web of Conferences}

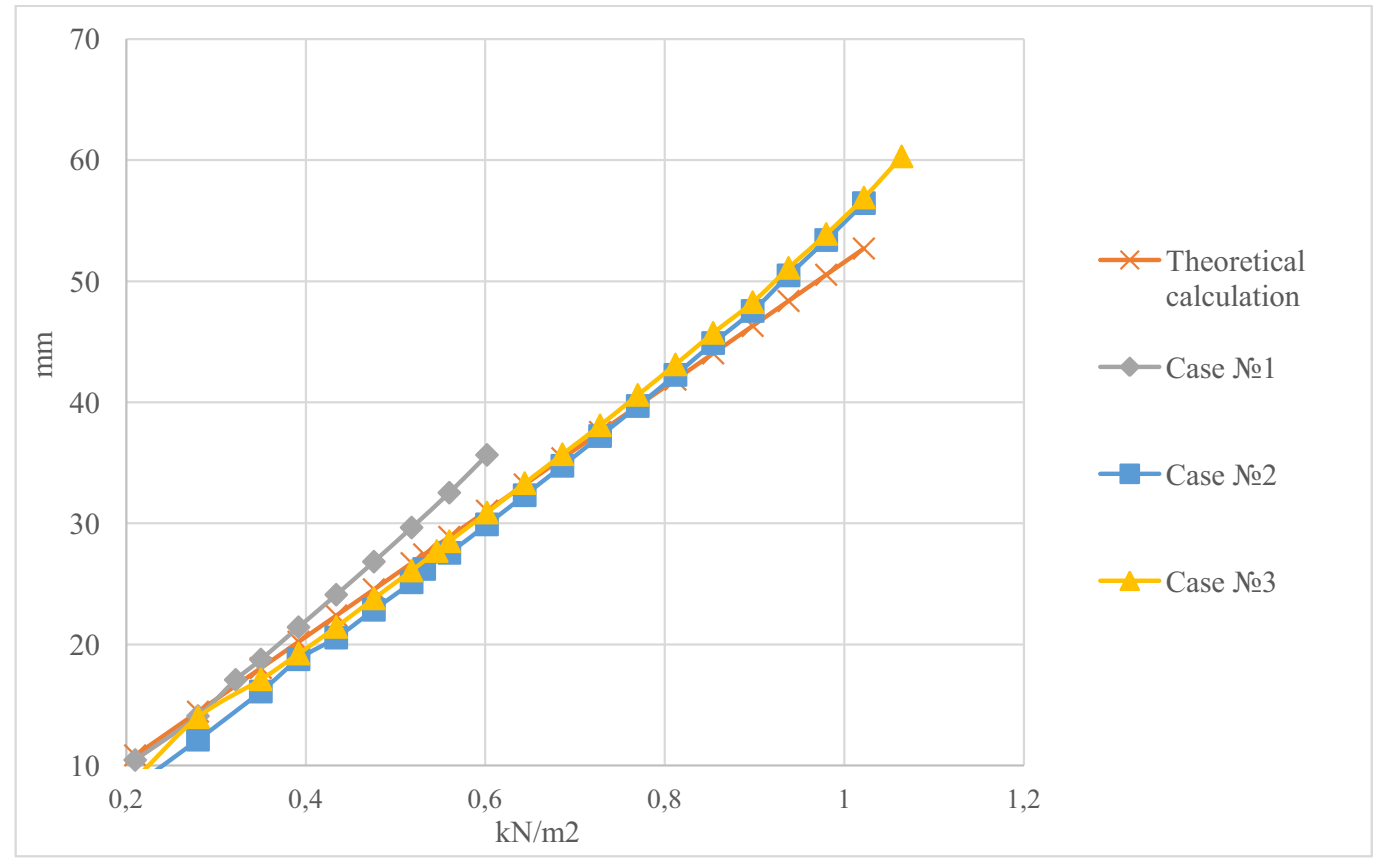

Figure 2. The dependence deflection of the beam from uniformly distributed load, according to data of test sandwichpanels MEGA SP-Z-100-MV with $6 \mathrm{~m}$ span and theoretical calculation

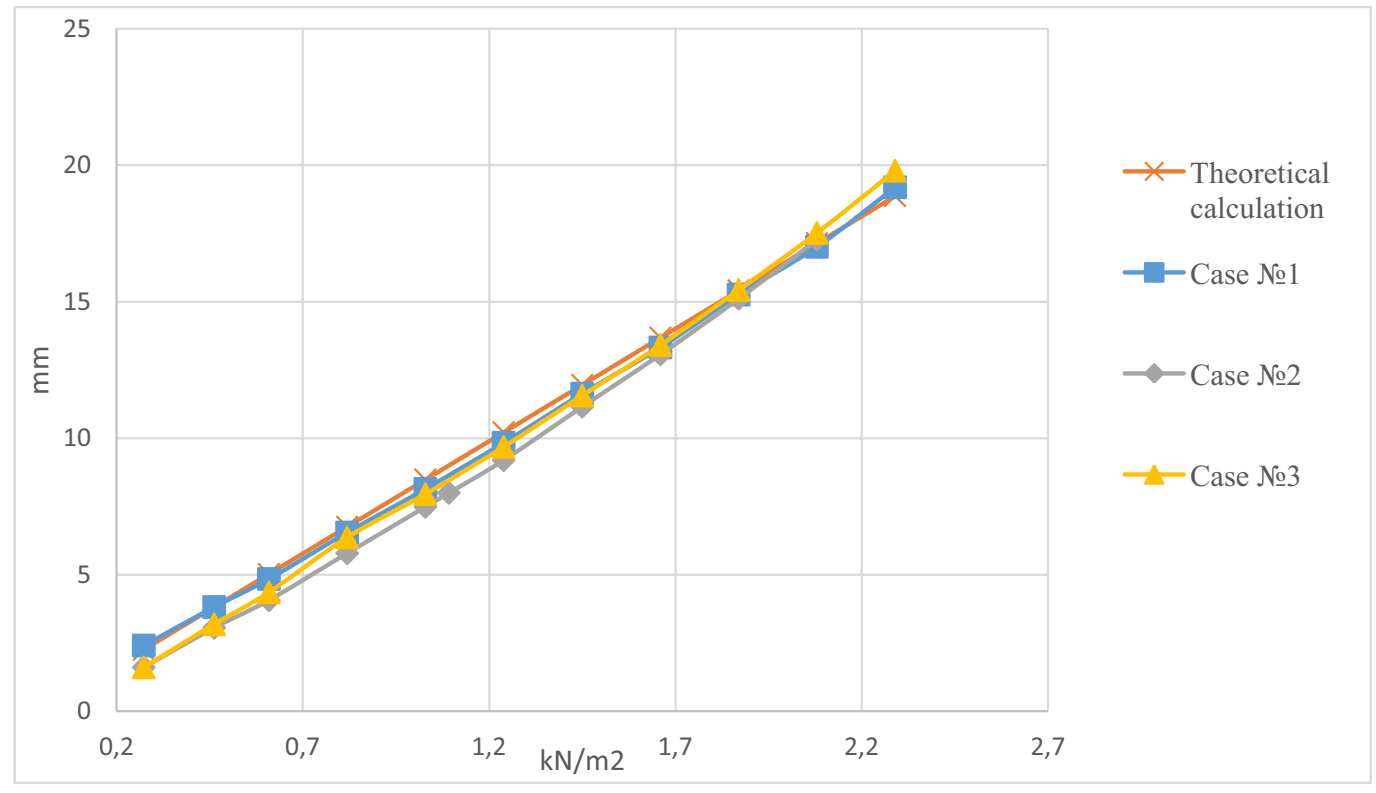

Figure 3. The dependence deflection of the beam from uniformly distributed load, according to data of test sandwichpanels MEGA SP-Z-150-MV with $4 \mathrm{~m}$ span and theoretical calculation 


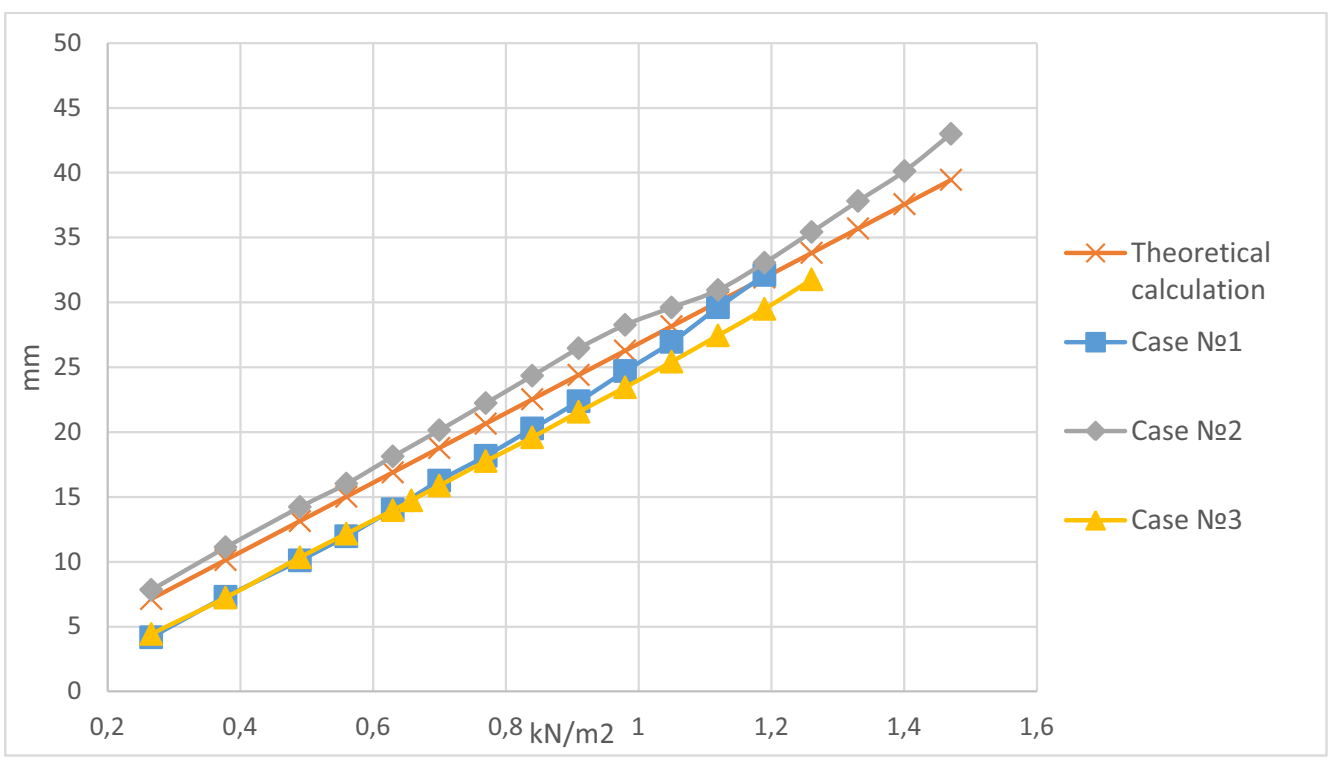

Figure 4. The dependence deflection of the beam from uniformly distributed load, according to data of test sandwichpanels MEGA SP-Z-150-MV with $6 \mathrm{~m}$ span and theoretical calculation

Table 3. The value of critical loads and damage mechanisms made by theoretical and actual cases

\begin{tabular}{|c|c|c|c|c|c|}
\hline & $\begin{array}{c}\text { The } \\
\text { length of } \\
\text { span }\end{array}$ & $\begin{array}{c}\text { Theoretical } \\
\text { critical load, } \\
q_{c r} \\
\end{array}$ & $\begin{array}{c}\text { The } \\
\text { damage mechani } \\
\text { sms }\end{array}$ & $\begin{array}{l}\text { Actual critical } \\
\text { load, } q_{c r}\end{array}$ & The damage mechanisms \\
\hline \multirow{6}{*}{$\begin{array}{l}\text { MEGA SP- } \\
\text { Z-100-MV }\end{array}$} & \multirow{3}{*}{$\mathrm{L}=4 \mathrm{~m}$} & \multirow{3}{*}{$\begin{array}{c}2.27 \mathrm{kN} / \mathrm{m} 2 \\
(1.82 \mathrm{kN} / \mathrm{m} 2)\end{array}$} & \multirow{3}{*}{$\begin{array}{l}\text { Wrinkling of } \\
\text { compressed face } \\
\text { in the span } \\
(\gamma \mathrm{m}=1.25)\end{array}$} & $1.05 \mathrm{kN} / \mathrm{m} 2$ & $\begin{array}{l}\text { Wrinkling of compressed face in the span at a } \\
\text { distance of } 3 / 8 \text { of the support }\end{array}$ \\
\hline & & & & $1.47 \mathrm{kN} / \mathrm{m} 2$ & $\begin{array}{l}\text { Wrinkling of compressed face in the span at a } \\
\text { distance of } 300 \mathrm{~mm} \text { of the support }\end{array}$ \\
\hline & & & & $1.81 \mathrm{kN} / \mathrm{m} 2$ & $\begin{array}{l}\text { Wrinkling of compressed face in the span at a } \\
\text { distance of } 500 \mathrm{~mm} \text { of the support }\end{array}$ \\
\hline & \multirow{3}{*}{$\mathrm{L}=6 \mathrm{~m}$} & \multirow{3}{*}{$\begin{array}{c}1.01 \mathrm{kN} / \mathrm{m} 2 \\
(0.81 \mathrm{kN} / \mathrm{m} 2)\end{array}$} & \multirow{3}{*}{$\begin{array}{l}\text { Wrinkling of } \\
\text { compressed face } \\
\text { in the span } \\
(\gamma \mathrm{m}=1.25)\end{array}$} & $0.64 \mathrm{kN} / \mathrm{m} 2$ & $\begin{array}{l}\text { Wrinkling of compressed face in the span at a } \\
\text { distance of } 3 / 8 \text { of the support }\end{array}$ \\
\hline & & & & $1.06 \mathrm{kN} / \mathrm{m} 2$ & $\begin{array}{l}\text { Wrinkling of compressed face in the middle } \\
\text { part in the span }\end{array}$ \\
\hline & & & & $1.09 \mathrm{kN} / \mathrm{m} 2$ & $\begin{array}{l}\text { Wrinkling of compressed face in the span at a } \\
\text { distance of } 3 / 8 \text { of the support }\end{array}$ \\
\hline \multirow{6}{*}{$\begin{array}{l}\text { MEGA SP- } \\
\text { Z-150-MV }\end{array}$} & \multirow{3}{*}{$\mathrm{L}=4 \mathrm{~m}$} & \multirow{3}{*}{$\begin{array}{c}3.00 \mathrm{kN} / \mathrm{m} 2 \\
(2.40 \mathrm{kN} / \mathrm{m} 2)\end{array}$} & \multirow{3}{*}{$\begin{array}{l}\text { Compression of } \\
\text { the core over a } \\
\text { support } \\
(\gamma \mathrm{m}=1.4)\end{array}$} & $2.48 \mathrm{kN} / \mathrm{m} 2$ & Compression of the core over a support \\
\hline & & & & $2.23 \mathrm{kN} / \mathrm{m} 2$ & Compression of the core over a support \\
\hline & & & & $2.48 \mathrm{kN} / \mathrm{m} 2$ & Compression of the core over a support \\
\hline & \multirow{3}{*}{$\mathrm{L}=6 \mathrm{~m}$} & \multirow{3}{*}{$\begin{array}{c}1.51 \mathrm{kN} / \mathrm{m} 2 \\
(1.21 \mathrm{kN} / \mathrm{m} 2)\end{array}$} & \multirow{3}{*}{$\begin{array}{l}\text { Wrinkling of } \\
\text { compressed face } \\
\text { in the span } \\
(\gamma \mathrm{m}=1.25)\end{array}$} & $1.26 \mathrm{kN} / \mathrm{m} 2$ & $\begin{array}{l}\text { Wrinkling of compressed face in the middle } \\
\text { part in the span }\end{array}$ \\
\hline & & & & $1.54 \mathrm{kN} / \mathrm{m} 2$ & $\begin{array}{c}\text { Wrinkling of compressed face in the middle } \\
\text { part in the span }\end{array}$ \\
\hline & & & & $1.32 \mathrm{kN} / \mathrm{m} 2$ & $\begin{array}{l}\text { Wrinkling of compressed face in the middle } \\
\text { part in the span }\end{array}$ \\
\hline
\end{tabular}

The results of the experiment it is possible to create a table with the actual breaking load for each case and compare it with the results obtained by means of calculation (Table 3). It should be noted that in each of these tests delamination facing from insulation was observed, whereby facing lost it's resistance and failure occurs. Also the table shows that, the data theoretically obtained on the strength are overstated and failure 


\section{MATEC Web of Conferences}

occurs at lower loads, but the load carrying capacity "sandwich" - panels enough to use them as building envelopes. To use of sandwich panels as constructive bearing elements, it is necessary to reduce the variation of critical loads. The table shows that most of the panels can bear load that stated on the calculation, but in order to ensure the strength of the panels is necessary to understand why the calculated bearing capacity is overstated. To do this, pay attention to the feature of fracture, namely, the peeling of insulation from the facing. This may mean that the glue does not provide sufficient compound of components of panel or insulation is not sufficient shear strength in the longitudinal plane. When making more stringent requirements at the manufacturing stage, in particular, can be used methods of nondestructive testing [18] to control of mechanical damage actually achieve stability in the destruction, then should adjust the calculated method of reliability coefficients of material and tests to confirm the results. After these measures, it will be possible to recommend the use of "sandwich" - panels as bearing structures in practice.

On the other hand, it is possible to approach the problem from the new constructive solutions, in particular as an example of technological solutions of this problem can be leaded work of H. Kim [29] or Petrova EA [30], which proposed to strengthen the construction of sandwich panels by reinforcing elements.

\section{The conclusion}

As a result, were analyzed the method of estimating the stress-strain state calculation of sandwich panels proposed by source [26]. It can be concluded that the method of sufficiently accurately describes the behavior of this material, however due to volatility characteristics of each individual panel is currently not possible to ensure sufficient carrying capacity of this material for using as a structural load-bearing elements. It should be the introduction of more stringent requirements for the production of sandwich-panels in the case of their application as load-bearing structures to solve the problem.

\section{References}

[1] TУ 5284-003-79850813 (2010)

[2] A. Gorshkov, N. Vatin, D. Nemova, A. Shabaldin, L. Melnikova, P. Kirill, Procedia Engineering, 117 (1), 1085-1094 (2015)

[3] N. Harmati, Z. Jakšić, N. Vatin, Procedia Engineering, 117 (1), pp. 791-799 (2015)

[4] N. Vatin, A. Gorshkov, P. Rymkevich, D. Nemova, D. Tarasova, Applied Mechanics and Materials, 670-671, $365-369$ (2014)

[5] N. Vatin, A. Gorshkov, A. Kazimirova, K. Gureev, D. Nemova, Journal of Applied Engineering Science, 12 (3), 207-216 (2014)

[6] M. Penić, N. Vatin, V. Murgul, Applied Mechanics and Materials, 680, 534-538 (2014)

[7] V. Pukhkal, M. Tanić, N. Vatin, V. Murgul, Procedia Engineering, 117, 864-869 (2015)

[8] E. Aronova, N. Vatin, V. Murgul, Procedia Engineering, 117 (1), 771-779 (2015)

[9] M. Tanic, D. Stankovic, V. Nikolic, M. Nikolic, D. Kostic, A. Milojkovic, S. Spasic, N. Vatin, 2015, Procedia Engineering, 117 (1), 924-937 (2015)

[10] N.I. Vatin, D.V. Nemova, D.S. Tarasova, A.A. Staritcyna, Advanced Materials Research, 953-954, 854-870 (2014)

[11] N.I. Vatin, D.V. Nemova, A.S. Kazimirova, K.N. Gureev, Advanced Materials Research, 953-954, 1537-1544 (2014)

[12] V. Ermoshkin, S. Dymovskih, I. Vojlokov, S. Yakubov, StrojProfil, 2(72), 33-34 (2009)

[13] E. Petrova, O. Kalmykov, Gorodskoe kommunalnoe hozyajstvo, 38-44 (2015)

[14] Recommendations on determination, CNIIPSK them Mel'nikova, 1-44 (2013)

[15] O. Tusnina, M. Hejnisuo, Promyshlennoe i grazhdanskoe stroitel'stvo, 67-70 (2012)

[16] O. Tusnina, A. Danilov, Vestnik MGSU, 26-36 (2014)

[17] M. Georgescu, V. Ungureanu, Thin-Walled Structures, 242-249 (2014)

[18] M. Kujawa, C. Szymczak, Thin-Walled Structures, 43-52 (2014)

[19] K. Sad Saoud, P. Le Grognec, Thin-Walled Structures, 13-23 (2014)

[20] R. Studziński, Z. Pozorski, A. Garstecki, Journal of Constructional Steel Research, 227-234 (2014)

[21] B. Gosowski, M. Gosowski, Journal of Constructional Steel Research, 53-60 (2014)

[22] S. Petrov, E. Il'diyarov, N. Popkov, I. Holopov, M. Mosesov, A. Solov'yov, $44-47$ (2009)

[23] S. Petrov, Stroitel'naya mekhanika i raschyot sooruzhenij, 27-33 (2010)

[24] I. Holopov, S. Petrov, Promyshlennoe i grazhdanskoe stroitel'stvo, 36-40 (2013)

[25] Self-supporting double skin metal faced insulating panels, EN 14509, (2013)

[26] M. Davies, CIB Working Commission, 195-204 (2001)

[27] Metal panels with insulation foam. General specifications, GOST 32603, (2012)

[28] L. Pieczonkaa, F. Aymerichb, W. J. Staszewskia, International Symposium on Dynamic Response and Failure of Composite Materials, 216-221 (2014)

[29] H. Kim, B. Hyun Cho, H. Hur, K. Kang, Materials \& Design, 231-242 (2015)

[30] E. Petrova, Collection of scientific articles, 26-43 (2015) 